\title{
Distal protection beneficial?
}

\author{
E. E. van der Wall $\cdot$ J. J. Bax $\cdot$ J. W. Jukema \\ M. J. Schalij
}

Received: 9 November 2009/Accepted: 10 November 2009/Published online: 20 November 2009

(C) The Author(s) 2009. This article is published with open access at Springerlink.com

The pathogenesis of acute coronary syndromes (ACS) includes the rupture or erosion of a coronary atherosclerotic plaque with variable degrees of superimposed platelet aggregation inducing a thrombus [1]. ST-elevation myocardial infarction (STEMI) is often caused by a total coronary occlusion of the atherothrombotic plaque, whereas in non-ST-elevation myocardial infarction (NSTEMI) the thrombus is mainly nonocclusive or transient occlusive causing less myocardial damage [2]. Conventional percutaneous coronary intervention (PCI) focuses on compressing the atherothrombotic plaque with the aim to normalize flow in the coronary artery and therefore restore perfusion of the ischemic myocardium [3]. However, embolization of atherothrombotic material may occur spontaneously after plaque rupture or due to mechanical crushing of the culprit lesion during PCI [4]. This results in obstruction of distal vessels or the microcirculation in the down-stream bed of the ischemia-related artery. Although normal epicardial flow may be achieved, this will lead to diminished myocardial perfusion, which is associated with larger

Editorial comment on the article of Duan et al. (doi:10.1007/s10554-009-9513-7).

E. E. van der Wall $(\bowtie) \cdot$ J. J. Bax · J. W. Jukema ·

M. J. Schalij

Leiden University Medical Center, Leiden

The Netherlands

e-mail: E.E.van_der_Wall@lumc.nl infarct size, diminished left ventricular ejection fraction and increased mortality [5]. Microvascular obstruction is frequently implicated as the underlying cause through the mechanism of embolization [6-8]. Distal protection devices (DPDs) can be used for transient distal balloon occlusion during PCI, and allow recovery of any liberated plaque by aspiration before restoration of the antegrade flow [9]. Whether myocardial function can be improved with DPDs compared with conventional PCI in patients with acute myocardial infarction (AMI) has still to be proven. Over the years, echocardiography [10-13] and CMR [14-37] have found a fixed niche in the setting of AMI. In particular CMR allows the visualization of infarct site and size whereby the identification of microvascular obstruction has become unique to CMR [38-40].

For echocardiography, there are limited data describing changes in cardiac function in DPDs studies, and no data describing changes in regional myocardial function. Tissue Doppler imaging (TDI) is a useful echocardiographic tool that permits quantitative and objective assessment of both global and regional function [41-43].

In the current issue of the International Journal of Cardiovascular Imaging, Duan et al. [44] assessed the effects of DPDs on global and regional LV systolic and diastolic function were assessed by TDI in 69 patients with anterior AMI, who were randomly assigned to either PCI with DPDs (DPD group, $n=46$ ) or conventional PCI (control group, $n=50$ ). 
At 3- and 6-month follow-up, the DPD group showed a higher LV ejection fraction than the control group. Moreover, peak systolic and early diastolic mitral annular velocities obtained by TDI were significantly higher in the DPD group than in the control group. Lastly, the systolic and diastolic regional myocardial velocities were significantly improved in the DPD group compared to the control group. The authors concluded that patients with DPDs showed significant improvement of LV function. Especially patients with anterior AMI may benefit from DPDs during PCI.

In recent years various distal protection devices and thrombectomy devices have been developed to protect the microcirculation against embolization of atherothrombotic material and to improve myocardial reperfusion and LV function after PCI [45]. As the use of distal protection devices is still under debate, several trials in patients with STEMI have recently focused on thrombus aspiration [46-49]. These trials have clearly shown that thrombus aspiration improves myocardial reperfusion compared to conventional PCI. The largest study to date, the TAPAS-trial, showed that manual thrombus aspiration using the Export Aspiration Catheter (EAC) in patients with STEMI improves myocardial perfusion and one-year clinical outcome compared to conventional PCI [47]. As a consequence, thrombus aspiration has been included in the new European guidelines for patients with STEMI as a therapy to improve myocardial perfusion [50]. To conclude, the study of Duan et al. [44] lends support to the notion that distal protection may be beneficial in patients with STEMI.

Open Access This article is distributed under the terms of the Creative Commons Attribution Noncommercial License which permits any noncommercial use, distribution, and reproduction in any medium, provided the original author(s) and source are credited.

\section{References}

1. Thim T, Hagensen MK, Bentzon JF, Falk E (2008) From vulnerable plaque to atherothrombosis. J Intern Med 263:506-516

2. van der Laarse A, Kerkhof PL, Vermeer F et al (1988) Relation between infarct size and left ventricular performance assessed in patients with first acute myocardial infarction randomized to intracoronary thrombolytic therapy or to conventional treatment. Am J Cardiol 61:1-7
3. Van't Hof AW, Liem A, Suryapranata H, Hoorntje JC, de Boer MJ, Zijlstra F (1998) Angiographic assessment of myocardial reperfusion in patients treated with primary angioplasty for acute myocardial infarction: myocardial blush grade. Zwolle myocardial infarction study group. Circulation 97:2302-2306

4. Henriques JP, Zijlstra F, Ottervanger JP et al (2002) Incidence and clinical significance of distal embolization during primary angioplasty for acute myocardial infarction. Eur Heart J 23:1112-1117

5. Hoffmann R, Lepper W, Heussen N et al (2004) Impact of flow level on coronary flow velocity pattern. A doppler flow study in patients with first acute myocardial infarction. Int J Cardiovasc Imaging 20:27-35

6. van Dockum WG, Knaapen P, Hofman MB et al (2009) Impact of alcohol septal ablation on left anterior descending coronary artery blood flow in hypertrophic obstructive cardiomyopathy. Int J Cardiovasc Imaging 25:511-518

7. Marques KM, Westerhof N (2008) Characteristics of the flow velocity-pressure gradient relation in the assessment of stenoses: an in vitro study. Neth Heart J 16:156-162

8. Freund MW, Schouten T, Lemmers P, Schroer C, Strengers J (2008) Successful percutaneous balloon valvuloplasty in a preterm infant weighing $1,500 \mathrm{~g}$ with critical pulmonary valve stenosis. Neth Heart J 16:264-266

9. Srinivasan M, Rihal C, Holmes DR, Prasad A (2009) Adjunctive thrombectomy and distal protection in primary percutaneous coronary intervention: impact on microvascular perfusion and outcomes. Circulation 119:1311-1319

10. Kamp O (2008) History of echocardiography in the Netherlands: 30 years of education and clinical applications. Neth Heart J 16:16-20

11. Cramer MM, De Boeck BW (2007) Three-dimensional echocardiography and left bundle branch block: prime time in cardiology. Neth Heart J 15:87-88

12. Kleijn SA, Kamp O (2009) Clinical application of threedimensional echocardiography: past, present and future. Neth Heart J 17:18-24

13. Braun S, van der Wall EE, Emanuelsson H, Kobrin I (1996) Effects of a new calcium antagonist, mibefradil (Ro 40-5967), on silent ischemia in patients with stable chronic angina pectoris: a multicenter placebo-controlled study. The Mibefradil International Study Group. J Am Coll Cardiol 27:317-322

14. van der Wall EE, Vliegen HW, de Roos A, Bruschke AV (1995) Magnetic resonance imaging in coronary artery disease. Circulation 92:2723-2739

15. Bavelaar-Croon CD, Kayser HW, van der Wall EE et al (2000) Left ventricular function: correlation of quantitative gated SPECT and MR imaging over a wide range of values. Radiology 217:572-575

16. Bax JJ, Lamb H, Dibbets P et al (2000) Comparison of gated single-photon emission computed tomography with magnetic resonance imaging for evaluation of left ventricular function in ischemic cardiomyopathy. Am J Cardiol 86:1299-1305

17. Pluim BM, Beyerbacht HP, Chin JC et al (1997) Comparison of echocardiography with magnetic resonance imaging in the assessment of the athlete's heart. Eur Heart J 18:1505-1513 
18. van der Wall EE, den Hollander W, Heidendal GA, Westera G, Majid PA, Roos JP (1981) Dynamic myocardial scintigraphy with 123I-labeled free fatty acids in patients with myocardial infarction. Eur J Nucl Med 6:383-389

19. Braun S, van der Wall EE, Emanuelsson S, Kobrin I (1996) Effects of a new calcium antagonist, mibefradil (Ro 405967), on silent ischemia in patients with stable chronic angina pectoris: a multicenter placebo-controlled study. The Mibefradil International Study Group. J Am Coll Cardiol 27:317-322

20. Holman ER, Buller VG, de Roos A et al (1997) Detection and quantification of dysfunctional myocardium by magnetic resonance imaging. A new three-dimensional method for quantitative wall-thickening analysis. Circulation 95:924-931

21. van Rugge FP, Holman ER, van der Wall EE et al (1993) Quantitation of global and regional left ventricular function by cine magnetic resonance imaging during dobutamine stress in normal human subjects. Eur Heart J 14:456-463

22. Pluim BM, Lamb HJ, Kayser HW et al (1998) Functional and metabolic evaluation of the athlete's heart by magnetic resonance imaging and dobutamine stress magnetic resonance spectroscopy. Circulation 97:666-672

23. van Rugge FP, van der Wall EE, Spanjersberg SJ et al (1994) Magnetic resonance imaging during dobutamine stress for detection and localization of coronary artery disease. Quantitative wall motion analysis using a modification of the centerline method. Circulation 90:127-138

24. Nemes A, Geleijnse ML, van Geuns RJ et al (2008) Dobutamine stress MRI versus threedimensional contrast echocardiography: it's all black and white. Neth Heart J $16: 217-218$

25. Vliegen HW, Doornbos J, de Roos A, Jukema JW, Bekedam MA, van der Wall EE (1997) Value of fast gradient echo magnetic resonance angiography as an adjunct to coronary arteriography in detecting and confirming the course of clinically significant coronary artery anomalies. Am J Cardiol 79:773-776

26. van der Wall EE, Heidendal GA, den Hollander W, Westera G, Roos JP (1980) I-123 labeled hexadecenoic acid in comparison with Thallium-201 for myocardial imaging in coronary heart disease. A preliminary study. Eur J Nucl Med 5:401-405

27. Hoogendoorn LI, Pattynama PM, Buis B, van der Geest RJ, van der Wall EE, de Roos A (1995) Noninvasive evaluation of aortocoronary bypass grafts with magnetic resonance flow mapping. Am J Cardiol 75:845-848

28. Langerak SE, Vliegen HW, de Roos A et al (2002) Detection of vein graft disease using high-resolution magnetic resonance angiography. Circulation 105:328-333

29. Tulevski II, Hirsch A, Sanson BJ et al (2001) Increased brain natriuretic peptide as a marker for right ventricular dysfunction in acute pulmonary embolism. Thromb Haemost 86:1193-1196

30. van der Geest RJ, de Roos A, van der Wall EE, Reiber JH (1997) Quantitative analysis of cardiovascular MR images. Int J Card Imaging 13:247-258

31. van der Geest RJ, Niezen RA, van der Wall EE, de Roos A, Reiber JH (1998) Automated measurement of volume flow in the ascending aorta using MR velocity maps: evaluation of inter- and intraobserver variability in healthy volunteers. J Comput Assist Tomogr 22:904-911

32. de Roos A, Matheijssen NA, Doornbos J et al (1990) Myocardial infarct size after reperfusion therapy: assessment with Gd-DTPA-enhanced MR imaging. Radiology 176:517-521

33. de Roos A, Matheijssen NA, Doornbos J, van Dijkman PR, van Rugge PR, van der Wall EE (1991) Myocardial infarct sizing and assessment of reperfusion by magnetic resonance imaging: a review. Int J Card Imaging 7:133138

34. van Rugge FP, Boreel JJ, van der Wall EE et al (1991) Cardiac first-pass and myocardial perfusion in normal subjects assessed by sub-second Gd-DTPA enhanced MR imaging. J Comput Assist Tomogr 15:959-965

35. van Rugge FP, van der Wall EE, van Dijkman PR, Louwerenburg HW, de Roos A, Bruschke AV (1992) Usefulness of ultrafast magnetic resonance imaging in healed myocardial infarction. Am J Cardiol 70:1233-1237

36. Holman ER, van Jonbergen HP, van Dijkman PR, van der Laarse A, de Roos A, van der Wall EE (1993) Comparison of magnetic resonance imaging studies with enzymatic indexes of myocardial necrosis for quantification of myocardial infarct size. Am J Cardiol 71:1036-1040

37. Holman ER, van Rossum AC, Doesburg T, van der Wall EE, de Roos A, Visser CA (1996) Assessment of acute myocardial infarction in man with magnetic resonance imaging and the use of a new paramagnetic contrast agent gadolinium-BOPTA. Magn Reson Imaging 14:21-29

38. Beek AM, Nijveldt R, van Rossum AC (2010) Intramyocardial hemorrhage and microvascular obstruction after primary percutaneous coronary intervention. Int $\mathrm{J}$ Cardiovasc Imaging (in press)

39. Nijveldt R, Beek AM, Hirsch A et al (2008) 'No-reflow' after acute myocardial infarction: direct visualisation of microvascular obstruction by gadolinium-enhanced CMR. Neth Heart J 16:179-181

40. Beek AM, Nijveldt R, van Rossum AC (2010) Intramyocardial hemorrhage and microvascular obstruction after primary percutaneous coronary intervention. Int J Cardiovasc Imaging (in press)

41. Ypenburg C, van der Wall EE, Schalij MJ, Bax JJ (2008) Imaging in cardiac resynchronization therapy. Neth Heart $\mathrm{J}$ 16:S36-S40

42. Schuijf JD, Bax JJ, van der Wall EE (2007) Anatomical and functional imaging techniques: basically similar or fundamentally different? Neth Heart J 15:43-44

43. Bleeker GB, Bax JJ, Fung JW et al (2006) Clinical versus echocardiographic parameters to assess response to cardiac resynchronization therapy. Am J Cardiol 97:260-263

44. Duan YY, Zhang HB, Liu LW et al. (2010) Effects of distal protection on left ventricular function in acute anterior myocardial infarction: a Doppler echocardiographic study. Int J Cardiovasc Imaging (in press)

45. Roffi M, Mukherjee D (2009) Current role of emboli protection devices in percutaneous coronary and vascular interventions. Am Heart J 157:263-270

46. Svilaas T, Vlaar PJ, van der Horst IC et al (2008) Thrombus aspiration during primary percutaneous coronary intervention. N Engl J Med 358:557-567 
47. Vlaar PJ, Svilaas T, van der Horst IC et al (2008) Cardiac death and reinfarction after 1 year in the Thrombus Aspiration during Percutaneous coronary intervention in acute myocardial infarction study (TAPAS): a 1-year follow-up study. Lancet 371:1915-1920

48. Vlaar PJ, Diercks GF, Svilaas T et al (2008) The feasibility and safety of routine thrombus aspiration in patients with non-ST elevation myocardial infarction. Catheter Cardiovasc Interv 72:937-942

49. Kampinga MA, Vlaar PJ, Fokkema ML, Gu YL, Zijlstra F (2009) Thrombus aspiration during percutaneous intervention in acute non-ST-elevation myocardial infarction study (TAPAS II)-study design. Neth Heart J 17:409-413

50. Van de Werf F, Bax J, Betriu A et al (2008) Management of acute myocardial infarction in patients presenting with persistent ST segment elevation: The task force on the management of ST-segment elevation acute myocardial infarction of the European society of cardiology. Eur Heart J 29:2909-2945 